\section{人体傎例角度について（その 2)}

\author{
静㴊大学教賚部门山内 公雄, 平沢弹一郎 \\ 稲村 欣作
}

従来，人体の淔立姿勢の保持，扰よびその動摇などに ついては，古くから多くの研究がなされてきた。 そし て，この直立姿勢を持統する能力は，労働やスポーツの みならず日常生活に沶いてもその能率をたかめ，生産の 向上や技術の進歩にも役立つものと考える.

私たちは，前四にひき続き，久保式 Goniometer（傾 斜角度計）を使用して，HTV 会社員 106 名の䫟倒角度 を測定した。 あわせて Martin 氏法により生体計測を し，更に基䝪的な機能測定をも护施し，それらの結果が 姿勢保持能力の因子として，どのような関係をもつてい るかについて検㗅せんとするものである。

そこで，今四は正常人の䫟倒倒度が，如们なる斯们と 阽致をむつものか基䝪的段階としてまとめ，また機能的 な面として背筋力をとりあげ，ます闹傾との関係を検討 してみたものである.

顛倒危度つ絬果を要紛与ると，

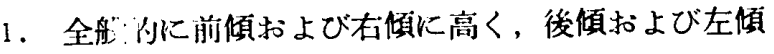
において低い傾向がある。
2. 開眼時は閉眼時より男女とも高い。

3. 男子の開服時と閉政時の差はすくない.

4. 女子の開服时と閉眼時の差怯特に大きい.

5. 男子は女子ょり開眼時，閉眼時ともに高い.

後今は更に，

1. 機能的な面, 形態的な面との関係.

2. 測定方法上の諸阙題.

3. 運動種目別, 職業別等の検討.

4. 筋電図, 脳波図による直立姿勢安定保持能力の究 明.

等について本研究をすすめていこうとするものである.

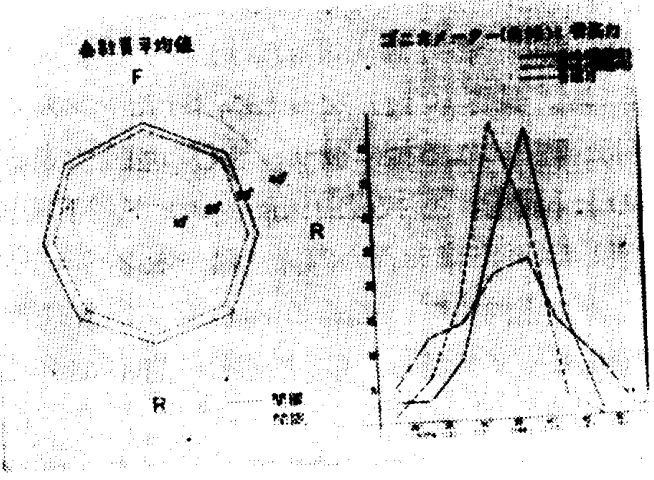

\section{朝きのリズムに関する研究（第3 報）}

\section{リスミカルな通功中の呼吸に及ほす伴奏の奻果} 山梨女子短大○石黒 節子，石黒 国椎 東京教育大学 松 本千代栄

舞踊に於けるリズムの特殊性を明らかにする日的で用门

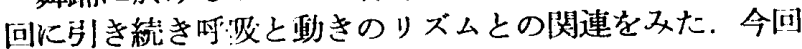
は，刺激としてのリズムをタクトを主としたトロノー ム、メロデイのあるフレーズをむつ音楽を伴奏とした場 合の呼吸波形の途いをみた。

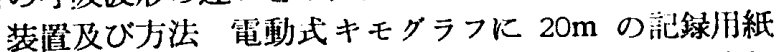
を使用しベン書きにした。呼伋運動は蛇管を胸部，腹部 にあてタンブールを通し記録した。 日時 41 叙 2 月〜3 月. 被験者 大学年女子 10 名 (運動経输なし). 測定項 目は，

\section{1 立位に於ける安静呼吸 1 分間} 立位儿於いて音楽を聞く 3 分間

1左右前後に 8 呼問で移動する動作を音楽に合わせ て行なら

II 上記の動作をメトロノームに合わせて行なら．各 史験闍に 14 日の間隔をおいた。

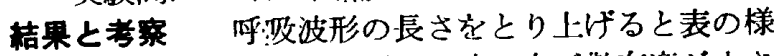
に安静，運動中共に音楽を聞いた時の方が散有度が小さ く，特に運動中は $\sigma=0.50$ で呼吸が一定するといらこ とがいえる，それを各分毎にみるとメトロノームの場合 は，最初の一分閌は $\sigma=0.62$ と著しく散布度が大きく， 2 分 3 分になるに従い他之平行状態になる。

呼吸波形の间さについて胸部腹部比分けて考察して及 ると，安静時も運動将も共に学楽を聞くことにより胸部
呼吸が浅くなり，腹部呼财が深くなる傾向がみられた。 動作中にエラーを生ずると呼吸が著しく乱れ，8時間の 動作にアクセントを加觉ることにより呼吸はアクヒント を中心とするフレーズが形成される。

従つて音湶を聞いたりズミカルな動作を行らことによ り时吸は一定となり，伴费がタクト们メトロノームより 害楽のもつ流動性（フレーズ）が動作上に良い初果を与 える.

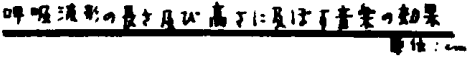

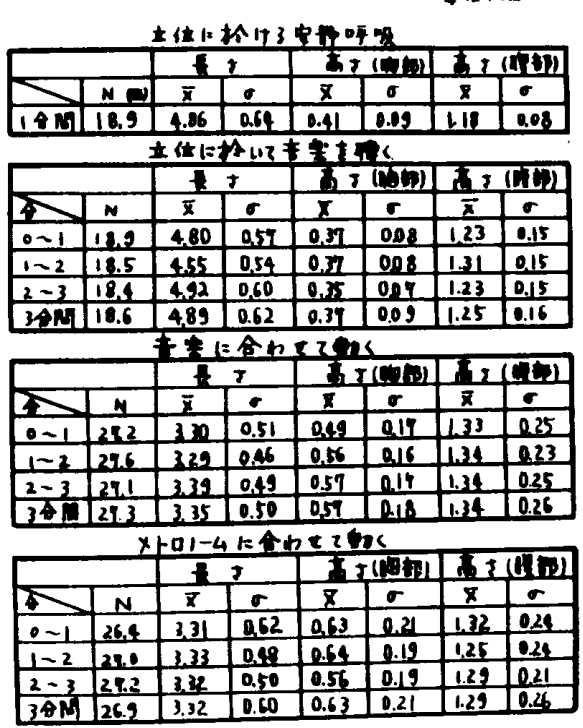

